\title{
Presently available biosimilars in hematology-oncology: G-CSF
}

\author{
Pere Gascon
}

Received: 1 August 2011 / Accepted: 1 August 2011 / Published online: 19 January 2012

(C) The Author(s) 2012. This article is published with open access at Springerlink.com

\begin{abstract}
Biopharmaceuticals were copies of endogenous human proteins developed in the mid-1990s that were characterized by complex three-dimensional, highmolecular weight compounds. What made them unique was that contrary to classical chemotherapeutical drugs, they were manufactured by living cells. One of these biopharmaceuticals was granulocyte-colony stimulating factor (G-CSF). Once their patent expired, generic versions appeared in pharmacies. They are now called biosimilars. There are several biosimilar G-CSFs approved in Europe: Biograstim ${ }^{\circledR} /$ Filgrastim ratiopharm/Ratiograstim ${ }^{\circledR} /$ Tevagrastim $^{\circledR}$ (XM02); Zarzio ${ }^{\circledR}$ and Nivestim ${ }^{\circledR}$. All these new products are manufactured in facilities with state-of-the-art technology. All products have passed the regulatory requirements for approval, mainly phase I and phase III, with the consequent $\mathrm{PD} / \mathrm{PK}$ evaluations and studies on efficacy and safety. However, there are still some concerns regarding their long-term evaluation, in particular, the limited experience at the time of approval of these products in terms of efficacy, safety and immunogenicity. For this reason, pharmacovigilance should be rigorous. A lot of work remains to be done in terms of clarification with regard to substituting a biosimilar G-CSF for the innovator product and, finally, information must be provided to physicians, pharmacists and patients to allow for proper decision-making. Ultimately, only clinical trials and effective post-marketing pharmacovigilance will provide definitive
\end{abstract}

This article is a reprint of Gascon P (2011) Presently available biosimilars in hematology-oncology_part II: G-CSFP. Oncologie 13 (5):213-217

P. Gascon $(\bowtie)$

Division of Medical Oncology, Hospital Clinic, IDIBAPS,

University of Barcelona,

Barcelona, Spain

e-mail: GASCON@clinic.ub.es evidence that a biosimilar is comparable to the originatorreference product in terms of efficacy and safety.

Keywords Biosimilars G-CSF · Biograstim · Ratiograstim • Tevagrastim $\cdot$ Zarzio $\cdot$ Nivestim

\section{Introduction}

By the mid-nineties, biopharmaceuticals were born, a new generation of chemotherapeutical agents. They were copies of endogenous human proteins characterized by complex three-dimension, high-molecular- weight compounds. They were made using either hybridoma or recombinant-DNA technology. Among them were hematopoietic white blood cell factors and, in particular, granulocytecolony stimulating factor (G-CSF). What made them unique and different from the classical chemotherapeutic agents was that were manufactured by living cells. Biopharmaceuticals are extremely similar one to another and to the reference molecule, but are not identical, no matter how close their similarities are.

Biopharmaceuticals are currently named "biosimilars" or "follow-on-protein products" by the European (European Medicines Agency) and the American regulatory agencies (Food and Drug Administration) respectively.

\section{G-CSF}

G-CSF is a 20,000-Dalton glycoprotein composed of a single polypeptide chain of 174 or 177 amino acids. It is glycosylated at threonine residue 133 . The native G-CSF is encoded by a gene on chromosome 17 that encodes two protein products due to differential splicing: isoform A of 
177 amino acids and isoform B of 174 amino acids. Isoform $\mathrm{A}$ differs from isoform $\mathrm{B}$ in that it contains an additional three residues (Val-Ser-Gln) inserted after Leu35. The 174-amino acid form is associated with greater biological activity and stability than the longer isoform and is the basis for commercial pharmaceutical G-CSF products, including Neupogen ${ }^{\circledR}$ (filgrastim). G-CSF is the most important hematopoietic growth factor for the recovery of neutrophils. It stimulates the proliferation of neutropenic progenitor cells and their differentiation to granulocytes, and functionally activates mature neutrophils [1].

Mechanism of action

Endogenous G-CSF is a lineage-specific colony-stimulating factor that is produced by monocytes, fibroblasts, and endothelial cells. G-CSF regulates the production of neutrophils within the bone marrow and affects neutrophil progenitor proliferation, differentiation, and selected cellfunctional activation (including enhanced phagocytic ability, priming of the cellular metabolism associated burst, antibodydependent killing, and the increased expression of some functions associated with cell-surface antigens). G-CSF is not species specific and has been shown to have minimal direct in vivo or in vitro effects on the production of hematopoietic cell types other than the neutrophil lineage.

It acts by binding to a specific transmembrane receptor (G-CSF Receptor), a member of the class I cytokine receptor family expressed on various hematopoietic cells such as stem cells, multi-potent progenitors, myeloidcommitted progenitors, neutrophils, and monocytes. The receptor forms homo-oligomeric complexes upon ligand binding. The effects of G-CSF are mediated via a single affinity class of receptors. The same mechanism of action and receptor-mediated biological activity operates in the mobilization of mature neutrophils into the circulating neutrophil pool and acceleration of granulopoiesis.

\section{Indications}

Neupogen ${ }^{\circledR}$ (Filgrastim) is one of the first biopharmaceutical human recombinant G-CSF products to be commercialized and the reference drug upon which all biosimilar G-CSFs have to be compared. It has been approved for the following clinical conditions [1]:

- Reduction of the duration of neutropenia and the incidence of febrile neutropenia in patients treated with established cytotoxic chemotherapy for malignancy (with the exception of chronic myelogenous leukemia and myelodysplastic syndromes) and reduction in the duration of neutropenia in patients undergoing myeloblastic therapy followed by bone marrow transplanta- tion considered to be at increased risk of prolonged severe neutropenia. This safety and efficacy of filgrastim are similar in adults and children receiving cytotoxic chemotherapy.

- Mobilization of peripheral blood progenitor cells.

- In patients (children or adults) with severe congenital, cyclic, or idiopathic neutropenia with an absolute neutrophil count (ANC) of $0,5 \times 10^{9} / \mathrm{L}$, and a history of severe or recurrent infections, long-term administration is indicated to increase neutrophil counts and to reduce the incidence and duration of infection-related events.

- Treatment of persistent neutropenia (ANC $1,0 \times 10^{9} / \mathrm{L}$ ) in patients with advanced HIV infection in order to reduce the risk of bacterial infections when other therapeutic options are inappropriate.

\section{Biosimilar G-CSFs}

Several biosimilar G-CSFs have been approved and will be discussed in this chapter (Biograstim ${ }^{\circledR} /$ Filgrastim ratiopharm/Ratiograstim ${ }^{\circledR} /$ Tevagrastim $^{\circledR}$ (XM02); Zarzio ${ }^{\circledR}$ and Nivestim $\left.{ }^{\circledR}\right)$.

\section{Biograstim/filgrastim ratiopharm/ratiograstim/ tevagrastim (XM02)}

\section{Active substance}

XM02 active substance is a recombinant human G-CSF produced in E. coli, yielding a non-glycosylated protein with an N-terminal methionyl extension (INN filgrastim). The protein is expressed in inclusion bodies followed by renaturation of protein and chromatographic purification steps. The protein is a recombinant form of the 174 aminoacid isoform that contains an additional $\mathrm{N}$-terminal methionine residue not found in the native human protein. The naturally occurring G-CSF is glycosylated at threonine residue 133, a modification that is absent in the active XM02 compound as an E. coli expression product $[2,3]$.

\section{Presentation}

The agent is supplied in pre-filled syringes containing $0.5 \mathrm{ml}$ (for the lower strength) or $0.8 \mathrm{ml}$ (for the higher strength) of sterile, preservative-free solution for injection consisting of 30 or 48 MIU (corresponding to 300 and $480 \mu \mathrm{g}$ respectively). XM02 active substance together with acidic sodium acetate buffer, sorbitol, polysorbate, and water are used for injection. The formulation is similar to Neupogen ${ }^{\circledR}$, and only slight differences exist in the 
concentration of polysorbate 80 and in the $\mathrm{pH}$ value. Administration is by subcutaneous or intravenous route, normally at a dose of 1 to $10 \mu \mathrm{g} / \mathrm{Kg} /$ day depending on the indication.

\section{Clinical studies}

Two phase I studies comparing to Neupogen ${ }^{\circledR}$ were performed in healthy volunteers. Mean serum concentration of $5 \mu \mathrm{g} / \mathrm{Kg}$ and $10 \mu \mathrm{g} / \mathrm{Kg}$ of the active compound of XM02 were similar to the ones of Neupogen ${ }^{\circledR}$. One single injection of the active XM02 compound produced the same CD34+ cell count peak at $72 \mathrm{~h}$ and returned to base-line levels after $336 \mathrm{~h}$, exactly as for Neupogen ${ }^{\circledR}$.

\section{Clinical efficacy}

Clinical efficacy was investigated in a pivotal study in patients with breast cancer who were treated with the reference product Neupogen ${ }^{\circledR}$ for up to four cycles of chemotherapy. Clinical efficacy of XM02 was considered to be comparable to Neupogen ${ }^{\circledR}$. There were no immunogenicity findings of clinical relevance, which had "major consequences for efficacy and safety" in the three studies. No antibody formation was identified.

\section{Safety}

Safety evaluations of XM02 have included analyses of five clinical studies: two phase I studies with healthy volunteers and three studies in cancer patients: breast cancer, lung cancer or non-Hodgkin's lymphoma. The lung cancer and non-Hodgkin's lymphoma studies were designed primarily to investigate the safety of XM02. In a pooled analysis of the three studies, the incidence of several treatmentemergent adverse events (TEAEs) (in cycle 1: alopecia, neutropenia, diarrhoea, asthenia, bone pain and abdominal pain) were statistically significantly higher in the Neupogen ${ }^{\circledR}$ only group than in the XM02-only group. However, these differences are unlikely to be of clinical relevance (Tables 1 and 2).

\section{Zarzio ${ }^{\circledR}$}

Filgrastim is produced by recombinant DNA technology in bacteria (E. coli) from the full length human sequence for N-(LMethionyl) granulocyte colony-stimulating factor (r-metHuG-CSF). Native G-CSF is a glycosylated protein but production in bacteria leads to a non-glycosylated product; however, this is still biologically active. The composition of Zarzio ${ }^{\circledR}$ is identical to the reference product Neupogen ${ }^{\circledR}$ except for the buffer system. The buffer for Zarzio ${ }^{\circledR}$ is glutamate and for Neupogen ${ }^{\circledR}$ it is acetate [4].

Presentation

Two presentations of the medicinal product are provided: 30MU $(300 \mu \mathrm{g} / 0.5 \mathrm{ml})$, solution for injection/concentration for solution for infusion-pre-filled syringe; and $48 \mathrm{MU}$ (480 $\mu \mathrm{g} / 0.5 \mathrm{ml})$, solution for injection/concentration for solution for infusion-pre-filled syringe.

\section{Clinical studies}

\section{Pharmakodynamic, pharmacokinetic studies}

Four pharmakodynamic/pharmacokinetic (PK/PD) studies were performed in healthy volunteers. PD activity was based primarily on ANC peak response and ANC exposure, i.e., the whole AUC over 10 days. The results of these studies support the comparability of the test and reference products with respect to their pharmacodynamic effect since absolute neutrophil count (ANC) curves are superimposable whatever the route and the dose. The CD34+ cell count after repeated dosing (secondary PD endpoint) showed a similar time profile for filgrastim and Neupogen ${ }^{\circledR}$ and AUEC0-216 h, PK. Serum levels of free G-CSF were lower after the administration of filgrastim than after that of Neupogen ${ }^{\circledR}$; the difference appeared consistent across the routes and doses and was statistically significant. There was a bioequivalence between the two products in terms of
Table 1 Approved biosimilars G-CSF

\begin{tabular}{llll}
\hline Trade name & Common name (INN) & Biosimilar sponsor & Reference product \\
\hline Biograstim $^{\circledR}$ & Filgrastim & CT Arzneimittel GmbH & Neupogen $^{\circledR}$ \\
Filgrastim ratiopharm $^{\circledR}$ & Filgrastim & Ratiopharm GmbH & Neupogen \\
Ratiograstim $^{\circledR}$ & Filgrastim & Ratiopharm GmbH & Neupogen \\
Tevagrastim $^{\circledR}$ & Filgrastim & Teva Generics GmbH & Neupogen \\
Zarzio $^{\circledR}$ & Filgrastim & Sandoz & Neupogen \\
Filgrastim HEXAL $^{\circledR}$ & Filgrastim & Hexal & Neupogen \\
Nivestim $^{\circledR}$ & Filgrastim & Hospira & Neupogen \\
\hline
\end{tabular}


Table 2 European public assessment reports comparison-filgrastim

Zarzio/filgrastim hexal Biograstim/filgrastim ratiopharm/ Nivestim

Product characteristics

\begin{tabular}{|c|c|c|c|}
\hline Produced & E. Coli & E. Coli & E. Coli \\
\hline Strength & $\begin{array}{l}\text { Two strengths: } 30 \mathrm{MU} / 0.5 \mathrm{ml} \text { and } \\
48 \mathrm{MU} / 0.5 \mathrm{ml} \text {. }\end{array}$ & $\begin{array}{l}\text { Two strengths: } 30 \text { or } 48 \mathrm{MIU} \\
\text { (corresponding to } 300 \text { and } 480 \mu \mathrm{g} \\
\text { respectively). }\end{array}$ & $\begin{array}{l}\text { Three strengths: } 120 \mu \mathrm{g} / 0.2 \mathrm{ml} \text {, } \\
300 \mu \mathrm{g} / 0.5 \mathrm{ml} \text { and } 480 \mu \mathrm{g} / \\
0.5 \mathrm{ml} \text {. }\end{array}$ \\
\hline $\begin{array}{l}\text { Medicinal } \\
\text { product }\end{array}$ & $\begin{array}{l}\text { Product composition of Zarzio and } \\
\text { Neupogen }{ }^{\circledR} \text { are quantitatively } \\
\text { identical except the buffer system, } \\
\text { glutamate for Zarzio and acetate for } \\
\text { Neupogen }{ }^{\circledR}\end{array}$ & $\begin{array}{l}\text { Buffered with acetate. Differs from } \\
\text { Neupogen }{ }^{\circledR} \text { only in } \mathrm{pH} \text { and in the } \\
\text { concentration of filgrastim and } \\
\text { polysorbate } 80 \text {. }\end{array}$ & Buffered with acetate. \\
\hline \multicolumn{4}{|l|}{ Pre-clinical data } \\
\hline Studies & $\begin{array}{l}6 \text { primary PD studies (4 in vitro); } 3 \\
\text { toxicology studies (comparative } \\
\text { repeat-dose toxicity, toxicokinetics, } \\
\text { local tolerance; no single-dose } \\
\text { toxicity study); no secondary PD } \\
\text { studies; no safety pharmacology } \\
\text { studies; no PK studies }\end{array}$ & $\begin{array}{l}6 \text { primary PD studies ( } 3 \text { in vitro); } 1 \\
\text { secondary PD study (in vitro); } 3 \text { safety } \\
\text { pharmacology studies; } 2 \text { PK studies; } 6 \\
\text { toxicology studies (repeat dose toxicity } \\
\text { study non-comparative) }\end{array}$ & $\begin{array}{l}\text { Primary PD studies: PD response } \\
\text { was determined in a neutropenic } \\
\text { rat model, as well as in healthy rat } \\
\text { in a repeat-dose toxicity study; no } \\
\text { secondary PD studies; no safety } \\
\text { pharmacology studies; PK } \\
\text { assessed as part of the repeat-dose } \\
\text { toxicity study; no single-dose } \\
\text { toxicity study }\end{array}$ \\
\hline \multicolumn{4}{|l|}{ Clinical data } \\
\hline $\begin{array}{l}\text { Phase I (PK/PD) } \\
\text { studies }\end{array}$ & $4 \mathrm{PK} / \mathrm{PD}$ studies in healthy volunteers & $2 \mathrm{PK} / \mathrm{PD}$ studies in healthy volunteers & $\begin{array}{l}2 \mathrm{PK} / \mathrm{PD} \text { studies in healthy } \\
\text { voluteers }\end{array}$ \\
\hline Phase III studies & $\begin{array}{l}1 \text { non-controlled study in patients with } \\
\text { breast cancer }\end{array}$ & $\begin{array}{l}3 \text { RCTS (patients with breast cancer, lung } \\
\text { cancer, NHL) }\end{array}$ & $\begin{array}{l}1 \mathrm{RCT} \text { in patients with breast } \\
\text { cancer }\end{array}$ \\
\hline Efficacy data & $\begin{array}{l}\text { Similar to Neupogen }{ }^{\circledR} \text { The } \\
\text { comparability of the efficacy based } \\
\text { on a PPD study in healthy volunteers } \\
\text { (absolute neutrophile and CS34+ cell } \\
\text { counts) was considered acceptable } \\
\text { by the CHMP. }\end{array}$ & $\begin{array}{l}\text { Similar to Neupogen }{ }^{\circledR} \text { There were no } \\
\text { statistically significant differences } \\
\text { between XM02 and Neupogen }{ }^{\circledR} \text { with } \\
\text { regard to the mean ANC nadir and with } \\
\text { regard to time to ANC recovery in the } \\
\text { studies. }\end{array}$ & $\begin{array}{l}\text { Similar to Neupogen }{ }^{\circledR} \text { There was } \\
\text { therapeutic equivalence between } \\
\text { the two products in terms of } \\
\text { efficacy with regard to the mean } \\
\text { ANC nadir and with regard to } \\
\text { time to ANC recovery. }\end{array}$ \\
\hline Safety data & Similar to Neupogen ${ }^{\circledR}$ & Similar to Neupogen ${ }^{\circledR}$ & Similar to Neupogen ${ }^{\circledR}$ \\
\hline
\end{tabular}

their elimination half-lives. It is acknowledged that the apparent difference in bioavailability may be overestimated due to the non-linear saturable pharmacokinetics of rhG-CSF, which is eliminated for a large part through binding to its target cells, neutrophils, and myeloid progenitors. Indeed, the difference in elimination characteristics at different doses may be related to the fact that receptor-mediated clearance (which is saturable) is predominant at lower doses, while renal clearance becomes more important at higher doses.

\section{Efficacy}

The comparability of the efficacy based on a study in healthy volunteers (absolute neutrophile and CD34+ cell counts) was considered acceptable by the Committee for Medicinal Products for Human Use (CHMP). Furthermore, the extrapolation to all indications of the reference products is acceptable since the mechanism of action is the same; i.e., direct stimulation of bone marrow cells through one specific type of surface receptor.

\section{Safety}

A direct comparison of the safety profile of the test and reference product was possible based on a total of four studies involving 146 healthy volunteers. ADRs associated with filgrastim were consistent with those reported in normal donors as described for Neupogen ${ }^{\circledR}$. Overall, these data supported the comparability of the products. The small single arm trial in cancer patients submitted allowed, to a certain extent, ruling out unexpected safety issues and suggested low immunogenicity of the test product. Additional long-term safety and immunogenicity data will be collected post-marketing (see Tables 1 and 2). 


\section{Nivestim ${ }^{\circledR}$}

Introduction

Nivestim ${ }^{\circledR}$ (also referred to as Pliva/Mayne filgrastim) is a 175-amino acid protein recombinant methionyl human granulocyte-colony stimulating factor (r-metHuG-CSF) that is produced in E. coli and has a molecular weight of 18,800 Da. Unlike the human protein, Nivestim ${ }^{\circledR}$ is unglycosylated and contains an N-terminal methionine. Filgrastim, the active substance of Nivestim ${ }^{\circledR}$ is a recombinant human G-CSF produced in E. coli as a nonglycosylated protein containing an N-terminal methionyl extension. It stimulates the proliferation, differentiation, and activation of late progenitor cells of the granulocyte lineage, as well as enhances the activity of mature neutrophils [5].

\section{Presentation}

Nivestim solution for injection or infusion comes in three strengths: $120 \mu \mathrm{g} / 0.2 \mathrm{ml}, 300 \mu \mathrm{g} / 0.5 \mathrm{ml}$, and $480 \mu \mathrm{g} /$ $0.5 \mathrm{ml}$. The qualitative and quantitative composition of Nivestim ${ }^{\circledR}$ and Neupogen ${ }^{\circledR}$ is the same, with the exception of the $120 \mu \mathrm{g} / 0.2 \mathrm{ml}$ presentation, which is not marketed by Amgen. However, this presentation only differs in fill volume from the $300 \mu \mathrm{g} / 0.5 \mathrm{ml}$ presentation.

\section{Clinical studies}

Two PD/PK studies were performed in healthy volunteers. Two phase I trials were carried out to study pharmacokinetics (PK) and demonstrate biosimilarity between Nivestim ${ }^{\circledR}$ and Neupogen ${ }^{\circledR}$, the reference product. The primary endpoint ANC AUC was also equivalent with both IV and SC administration compared to Neupogen ${ }^{\circledR}$. Results show that the mean ANC max, ANCmin, and CD34+ were equivalent for patients receiving both Nivestim ${ }^{\circledR}$ and Neupogen ${ }^{\circledR}$, and ANC Tmax occurred slightly earlier following treatment with Nivestim ${ }^{\circledR}(7.845 \mathrm{~h})$ compared to treatmentwithNeupogen ${ }^{\circledR}$ (9.448 h).

\section{Efficacy}

Its efficacy is similar to Neupogen ${ }^{\circledR}$. The clinical program for demonstrating biosimilarity between Nivestim $^{\circledR}$ and Neupogen ${ }^{\circledR}$ included one phase III study, which was conducted in patients with breast cancer who received G-CSF prophylaxis in addition to a normal chemotherapy. There was therapeutic equivalence between the two products in terms of efficacy with regard to the mean ANC nadir and with regard to time to ANC recovery.
Safety

Safety is similar to Neupogen ${ }^{\circledR}$. The Nivestim ${ }^{\circledR}$ study group showed a greater proportion of patients with severe neutropenia than the Neupogen ${ }^{\circledR}$ study group in cycle 1 (77.6\% versus $68.2 \%)$ and cycle 2. A lower proportion of Nivestim ${ }^{\circledR}$ patients experienced severe neutropenia in cycle 3 compared with that of Neupogen ${ }^{\circledR}$ patients. Duration of severe neutropenia was longer in the Nivestim study group. These findings were not statistically significant. The most common individual adverse reaction was bone pain; there was a higher incidence of bone pain in the Nivestim ${ }^{\circledR}$ group (Nivestim: $n=26,14.2 \%$; Neupogen: $n=9,9.5 \%$ ). All of these events were mild or moderate in nature except that involving one patient on Neupogen ${ }^{\circledR}$ who had severe pain in the extremity (see Tables 1 and 2).

\section{Summary}

Biosimilar G-CSF (Biograstim/Filgrastim ratiopharm/Ratiograstim/Tevagrastim (XM02); Zarzio and Nivestim) are manufactured in facilities with state-of-the-art technology. All products have passed the regulatory requirements for approval [6], mainly phase I and a phase III, with the consequent PD/PK evaluations and studies on efficacy and safety. However, as it has been largely discussed in this issue of Targeted Oncology, there are still some concerns for the long-term evaluation of these products, in particular, the limited experience at the time of approval of these products in terms of efficacy, safety, and immunogenicity. For this same reason, pharmacovigilance should be rigorous and is important as a public health concern. Guidelines will allow extrapolation of data to additional indications, for example, pediatric indication and PBPC in healthy donors. A lot of work remains to be done in terms of clarification with regard to substituting a biosimilar G-CSF for the innovator product and, finally, information must be provided to physicians, pharmacists, and patients to allow for proper decision-making. Ultimately, only clinical trials and effective post-marketing pharmacovigilance will provide definitive evidence that a biosimilar is comparable to the reference product in terms of efficacy and safety [7].

Conflict of interest statement The authors has received honoraria from Amgen and from Sandoz for lecturing.

Open Access This article is distributed under the terms of the Creative Commons Attribution Noncommercial License which permits any noncommercial use, distribution, and reproduction in any medium, provided the original author(s) and source are credited. 


\section{References}

1. Aapro MS, Bohlius J, Cameron DA et al (2011) 2010 update of EORTC guidelines for the use of granulocyte-colony stimulating factor to reduce the incidence of chemotherapyinduced febrile neutropenia in adult patients with lymphoproliferative disorders and solid tumours. Eur J Cancer 47(1): $8-32$

2. European Medicine Agency Evaluation of Medicines for Human Use. Assessment report for Tevagrastim. EMEA/503293/2008. Procedure no. EMEA/H/C/827
3. European Medicine Agency Evaluation of Medicines for Human Use. Assessment report for Ratiograstim EMEA/502481/2008. Procedure no. EMEA/H/C/825

4. European Medicine Agency Evaluation of Medicines for Human Use. Assessment report for Zarzio. EMEA/CHMP/651339/2008. Procedure no. EMEA/H/C/000917

5. European Medicines Agency. CHMO Assessment report for Nivestim. EMEA/262762/2010. Procedure no. EMEA/H/C/001142

6. Schellekens H (2009) Biosimilar therapeutics - what do we need to consider? NDT Plus 2(suppl I):i27-i36

7. Roger SD (2010) Biosimilars: current status and future directions. Expert Opin Biol Ther 10(7):1011-1018 